\title{
Effects of strong mining tremors, and assessment of the buildings' resistance to the dynamic impacts
}

\author{
Izabela Bryt-Nitarska, ${ }^{1, *}$ \\ ${ }^{1}$ The Strata Mechanics Research Institute PAN, Cracow, Poland
}

\begin{abstract}
A particularly important element in the assessment of the actual state of the threats which is caused by conducting the mining exploitation of seams bumping under the urban areas is to diagnose the condition of the land development after hard shocks. In the buildings, for which the impact of the mining activities, including the tremors, is not taken into account at the stage of design and formulation of the strength and use conditions, conclusions from the structure behaviour under the tremor influence are an essential part of the assessment of the possibility for transferring the further dynamic impacts. The use of conclusions from the in situ research has its role in anticipating the behaviour of the buildings in case of the forecast of the mining tremors effects in the regions of their impacts. These conclusions should also provide ground for the assumptions to the scope of the building prevention necessary to be taken in case of forecasting the tremors with big intensity. Based on the analysis of effects which occurred in the land development after the highenergy mining tremors, the elements of the dynamic resistance assessment for the buildings with traditional structure were discussed.
\end{abstract}

Keywords: dynamic resistance of the building, effects of mining shocks, strong mining shocks

\section{Introduction - concept of the resistance to mining impacts}

The mining impacts often cause deformations and damage in the building structure, that are unacceptable in the assessment of the standard ultimate limit states (ULS) and serviceability limit states (SLS) [1,2]. The possibility to accept, from time to time, the reduced requirements in the degree of meeting the SLS in the cubature objects subject to the mining impacts is practiced though. This approach is underpinned by the conclusions from the studies over the real behaviour of the structures under the conditions of load impacts derived from the mining area deformations [3]. While assessing the effects formed in the structure, a prerequisite is, however, the knowledge on the values of measuring indicators describing the occurred area deformation. With regard to the object it is required

* Corresponding author: nitarska@img-pan.krakow.pl 
to know the design and material conditions as well as the technical condition. The assessment of the construction object is conducted in the context of expected category of the mining area and foreseen dynamic impacts.

According to the definition formed in this paper [4], an object resistance is understood as capability for shifting the mining impact, expressed in the units of that impact, while not exceeding a specific technical condition of that object at the same time. With reference to the dynamic impacts, it means the possibility to accept additional forces formed in a building as a result of mining tremors [5]. The concept of such understood 'object resistance' is made for the procedure purposes enabling to carry out the exploitation of mineral deposits within the operation of underground mines under urban areas.

\section{Conditions for dynamic resistance of buildings}

For the brick buildings the resistance to the dynamic impacts, triggered by mining tremors in the ground base, determine mainly tensile and shear strength of the wall. The wall strength is a function of material features attributed to masonry units and binder. In the objects that are long-term used, the wall strength is affected also by the phenomena of shrinkage, creep and beyond-elastic strains in the strenuous parts of the structure [6,7]. A key determinant for the level of the real wall strength is the aging process related to the technical wear and the fatigue process resulting from multiple exposures to the dynamic loads $[8,9]$.

An impact resistance is also affected by the building mass spatial stiffness defined by non-dilatation strain [10], specific symmetry of the structure shape and the mass distribution uniformity from the self-weight loads. Elements responsible for the spatial structure stiffness are the applied system of stiffening walls, upholding the horizontal projection symmetry, stiffness of ceilings and their connection with the structure. In the buildings with wooden ceilings, for which the horizontal stiffness decrease is characteristic, an element determining the wall strength is also the wall stability (buckling) $[5,10,11]$.

As a result of the dynamic loads in the structure there are generated [6]:

- bending from the plane, for the walls located perpendicularly to the wave propagation direction,

- bending in the plane, for the walls located parallel to the wave propagation direction,

- shearing from the wall plane and in the wall plane.

In the existing buildings, the criterion of 'shock resistance' is the wall shear resistance and the horizontal member resistance. For the uniform wall, it is the load capacity in the corners and on the wall contacts as well as the load capacity in the places where the stiffness is impaired by openings. In the horizontal contacts, in the places where the slab roofs, ceilings and tie beams are supported on the wall, and the opening lintels, ceiling bearing beams and staircase beams. The criterion of 'shear resistance' refers also to free sections of masonry structure such as gable walls, attics, chimneys.

The wall shear resistance induced by horizontal inertia forces depends (directly proportional) on the degree of compressive stresses occurring in the strenuous crosssections $[6,7]$. In case of the wall subject to the shear parallel to the support joints, the exceeding of the wall resistance consists in the occurrence of 'a slip' in the support joint or on the contact of joint and bricks. Such damage arises in the wall structure with the mortar shear strength lower than the masonry units' tensile strength. In case when the mortar in the masonry structure is characterised with the shear strength bigger than the masonry units' tensile strength, and at the bigger compressive stresses, perpendicular to the support joints' surface, an oblique scratch appears in the wall. 
In practice, the structural system resistance depends on the current conditions within the range of real redistribution of internal forces related to the masonry structure condition, in particular, occurrence of wall geometrical discontinuity in form of scratches and cracks.

\section{Observed effects of the mining tremor impacts}

The presented examples of damage occurred in the land development which was subject to the impacts of many high-energy mining tremors during the last sixteen years. The tremors were generated by the exploitation realised in the seam characterised with high seismic activity. Over 100 tremors of energy around $10^{6} \mathrm{~J}$ were recorded in the exploitation area. The land development is also located within the range of impact of four incidental tremors with energy $7 \times 10^{7} \mathrm{~J} \div 8 \times 10^{8} \mathrm{~J}$, which occurred over a short period of time. The distance of the buildings from the tremor epicentre was each time from ca. $7 \mathrm{~m}$ to $1,000 \mathrm{~m}$. The measured maximum surface vibrations velocity might have been up to ca. $0,037 \mathrm{~m} / \mathrm{s}$. From the obtained distribution of the maximum amplitudes of the ground vibration acceleration resulted that the buildings might have been subject to the impact of the accelerations exceeding $1,2 \mathrm{~m} / \mathrm{s}^{2}$ and the value of maximum acceleration might have been ca. $1,9 \mathrm{~m} / \mathrm{s}^{2}[8,9]$.

The diagnostic measures were based on the inspections of the building structure damage taken after the strong tremors. In some buildings the author made the inspection three times over the 16 years. It enables to conduct the comparative analysis of the damage after the tremor with the previously recorded damage.

The buildings suffered a great deal of damage in the structural members. In the brick walls of a two-storey building stiffened with horizontal in-plane loaded plate over the ground floor, the scratches appeared, that are characteristic for torsional-flexural work of the wall corner and shear of wall derived from a variable as for the horizontal force direction - fig. 1 and 2 (acc. to [8]).

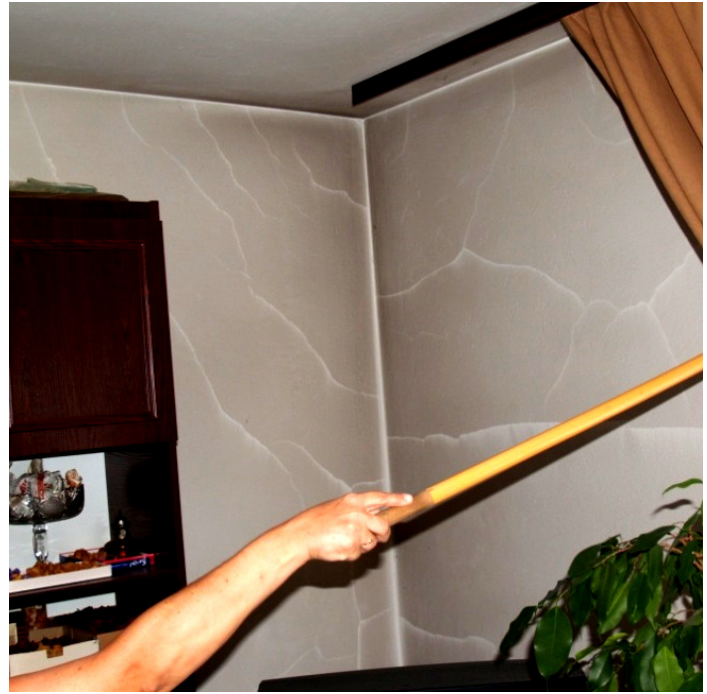

Fig. 1. Wall scratches in the area of the outer corner of the building

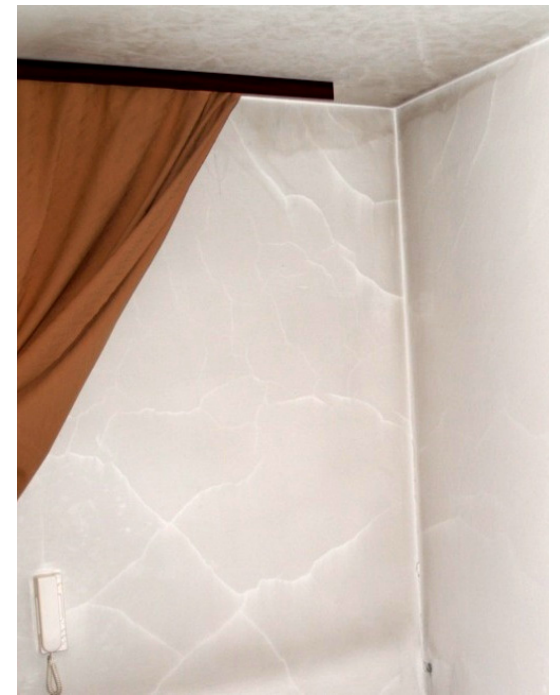

Fig. 2. Wall scratches in the area of the outer corner of the building

In the buildings with wooden ceilings which do not provide enough stiffening for loadbearing walls, the damage accumulated in the walls between windows. In many cases strong damage of lintels was observed, which under the conditions of multiple impact of 
tremors lead to disintegration of the masonry structures and require to be reconstructed fig. 3 and 4.

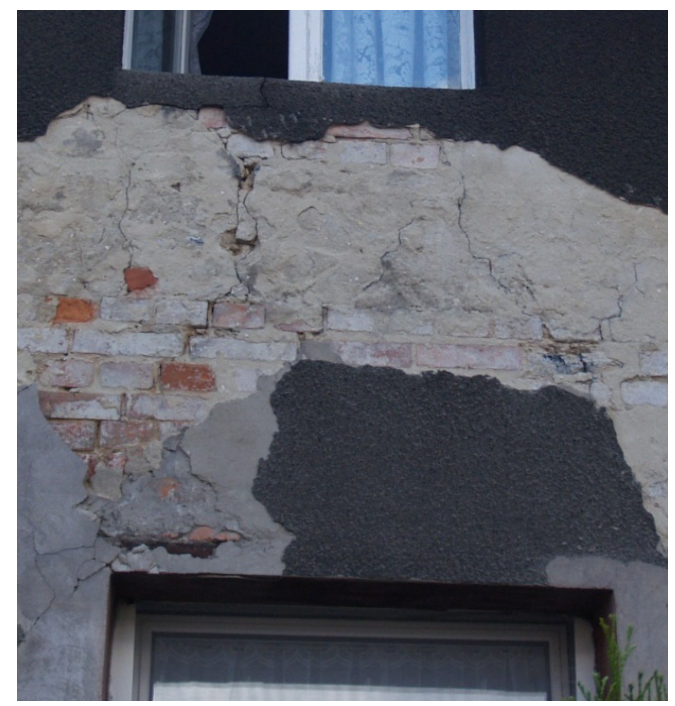

Fig. 3. Visible disintegration of the wall by the window

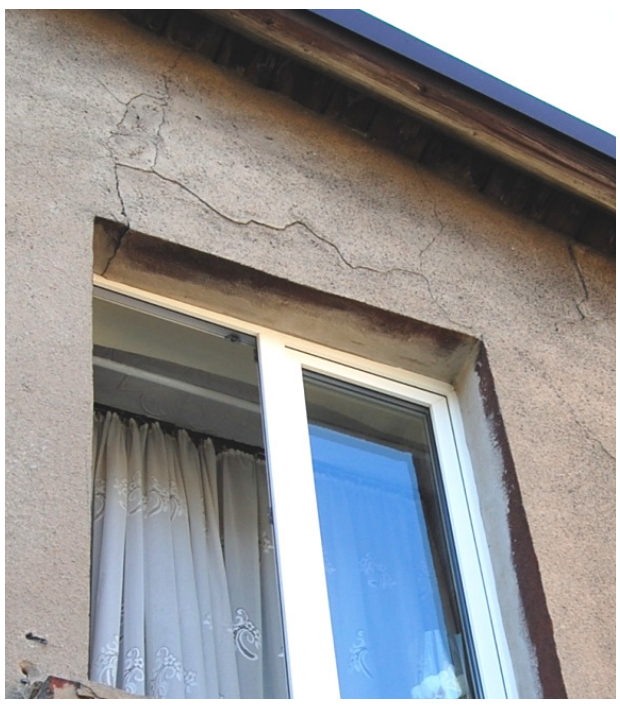

Fig. 4. Cracking and displacement of the lintel of the window

In the line of buildings erected in the industrial construction technology there were numerous horizontal shears of internal cross and long walls. Despite the fact that the walls are made of concrete, anti-shrinkage reinforced, in the places where the stiffness was impaired with the communication passage openings, strong cracks were made - fig. 5 and 6.

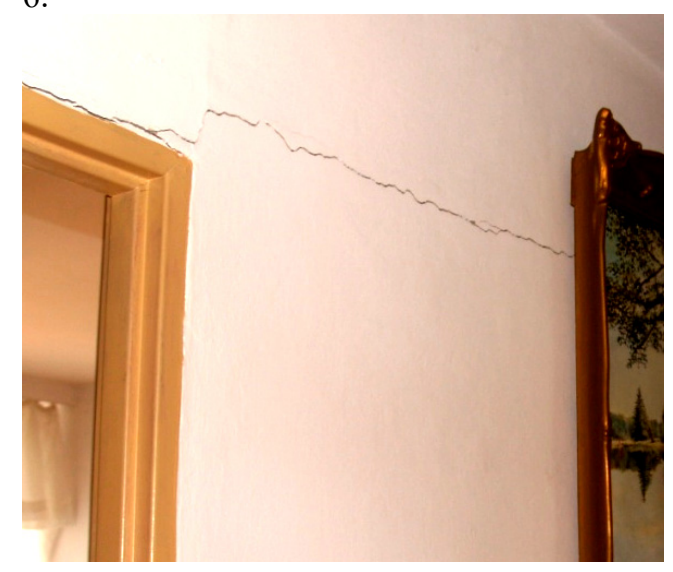

Fig. 5. Horizontal cracking of the concrete inner wall

For multi-segment development the criterion of resistance to the dynamic impacts includes also the width and passability of the maintained expansion gap. Improperly executed or filled expansion gaps cause the structure damage intensification in areas close to the expansion gaps.

A special case represents the damage of the concrete ceiling made with an economic method, while making a superstructure over a single storey building. The morphology of 
damage was managed to be analysed carefully only after hacking off the plasters. The horizontal cuts formed along the edges of the ceiling support and the scratches on the bottom plate surface result from the lack of properly shaped tie beam whose role is to provide restraint of the ceiling. Due to the dynamic impacts, the workmanship irregularities caused the formation of cracks in the support and span cross-sections - fig. 7 and 8 .

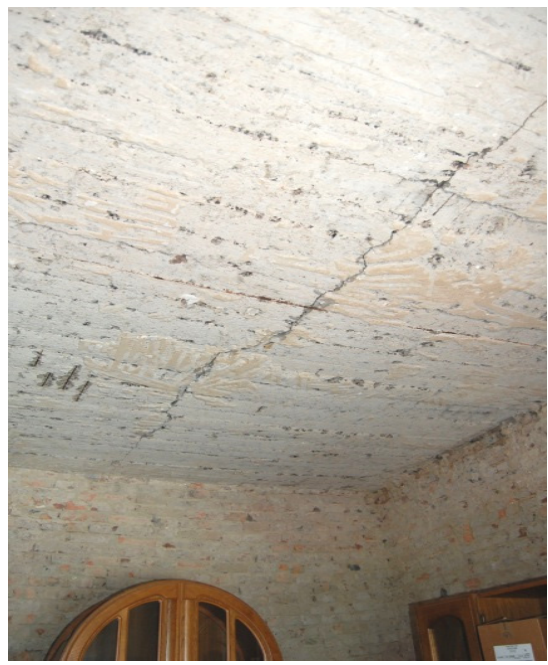

Fig. 7. Cracking of a reinforced concrete floor slab.

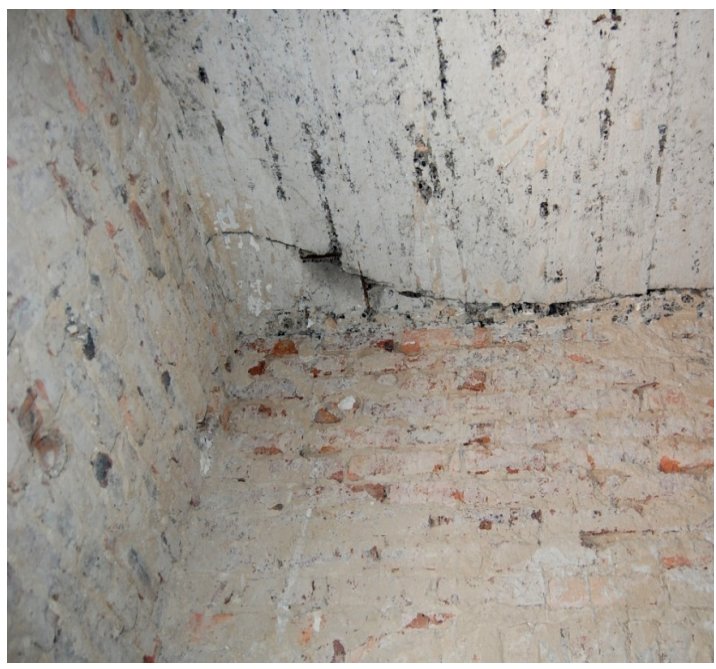

Fig. 8. Cracking of a reinforced concrete floor slab based on.

The damage was commonly stated in the finishing elements i.e. in the ceramic wall and/or floor linings, in the contacts of non-bearing walls e.g. gypsum plasterboards. In the buildings subject to several inspections, the intensification of the previously observed damage was found. The intensification consisted in increasing the openings of scratches or/and their length in the structural members and in the finishing elements.

\section{Determinants of the dynamic resistance assessment}

In the real conditions of impacts, the mining tremors cause the formation of torsionalflexural loads in the structure. The building parts are subject to variable displacements on a cyclical basis in plane and from plane forced by the structure torsion. The varied strength properties of the wall cause that the wall structures of the small-size elements are very susceptible to damage induced by the mining-origin tremors. In the potential risk assessment for occurrence of the damage that may threat local capacity or stability of the structure, the fact should be taken into account that due to strong tremors and multiple impacts of the dynamic load the arising horizontal forces may lead to the disintegration of the masonry structures. The multiple impacts of the dynamic loads substantially decrease the structure resistance to the vertical loads as well as to subsequent loads with horizontal forces. When the scratches appear in the ceramic linings, facade plasterwork or on the contacts of gypsum plasterboards under the conditions of multiple impacts of the dynamic loads, it indicates possible temporary overloads of the masonry structures. Whereas the scratches appearing on the contacts of prefabricated members, in the situation of tremor impact, may indicate the occurrence of excessive forced displacements of the structure.

In case when a building is located in the area of elevated seismic activity, an impact of single tremor on the structure condition cannot be considered. Since the whole history of 
loads decide on the condition of damage. Every subsequent tremor impact on the structure, particularly on those less resistant, causes its strength deterioration. Then, structure damage may appear even in the case when the impact of tremors is of the smaller intensity than the previous ones.

\section{Summary}

The assessment of structure strength to the mining loads should be always considered while taking into account the necessity for meeting the demands as for the basic requirements for the buildings, pursuant to Art. 5. p. 1 of the Act [12]. In mining regions, they are as follows: structure safety, serviceability safety and protection against (...) vibrations, mining tremors.

In no event of actual implementation of shifting additional mining loads, even while considering temporary reduced serviceability requirements, should be allowed to exceed the structure safety limit. In the assessment methodology for the building objects' dynamic resistance we cannot ignore the fact that dynamic phenomena of high intensity occur several times during their use. As a result of those impacts the structures suffer often minor damage which causes redistribution of forces and stresses as well as changes in the dynamic structure reaction conditions. The dynamic resistance of the buildings, over the course of time and occurrence of further dynamic phenomena, is declining.

In the near future we may encounter the real necessity for taking, more frequently than so-far, the reinforcements of the existing structures to the dynamic impacts.

\section{References}

1. PN-EN 1996-1-1 Eurokod 6. Projektowanie konstrukcji murowych.

2. PN-ISO 2394:2000 Ogólne zasady niezawodności konstrukcji budowlanych.

3. F. Pachla, T. Tatara: Odporność zabudowy mieszkalnej i gospodarczej na wpływy eksploatacji górniczej w obszarze górniczym KWK Janina. PAN (2017), nr 101, (str. 45-60).

4. J. Kwiatek, Obiekty budowlane na terenach górniczych. GIG, (2007).

5. B. Gil-Kleczeńska, J. Kwiatek, L. Muszyński. OTG, 71/1 (1985).

6. B. Lewicki, R. Jarmontowicz, J. Kubica: Podstawy projektowania niezbrojonych konstrukcji murowych. ITB, (2001).

7. B. Lewicki, Mat. Bud. no. 4/1999.

8. I. Bryt-Nitarska, GIG, no. $2 / 1 / 2011$ (p. $75 \div 84$ ).

9. I. Bryt-Nitarska. Miernictwo górnicze i ochrona terenów górniczych w obecnych warunkach wydobycia złóż surowców mineralnych w Polsce. AGH, 25-34 (2016).

10. J. Fedorowicz, M. Kawulok, GIG, no. 20 (1997).

11. E. Maciąg:Problemy Projektowania i Ochrony Obiektów Budowlanych na Terenach Górniczych, ITB, 1999.

12. Ustawa z dnia 7 lipca 1994 r. Prawo budowlane (Dz. U. poz. 1332). 